Brit. J. vener. Dis. (1961), 37, 240.

\title{
A NEW "ONE-MINUTE" TREATMENT OF GONORRHOEA*
}

\author{
BY
}

\author{
A. SIBOULET AND P. DUREL
}

Institut Fournier and Hôpital Saint-Louis, Paris

The treatment of gonorrhoea has once again become a problem, because of the risk of hypersensitivity reactions to penicillin, because streptomycin is now ineffective in many cases, and because patients can not be trusted to take oral treatment satisfactorily.

There is no lack of antibiotics capable of replacing penicillin or streptomycin; gonococci are sensitive to the majority of known antibiotics but, other than penicillin and streptomycin, these are almost all given orally.

In private practice and for certain clinic patients the use of oral treatment is not undesirable, but for the great majority of cases of gonorrhoea oral treatment does not find favour with venereologists. Indeed, there is no certainty that the prescribed dose will be taken and above all there is the definite risk that the patient will recommend the treatment to an infected friend or that he will have recourse to it himself should he become re-infected, and so evade medical supervision. It is unnecessary to point out the undesirability of these "self-treatments", which preclude epidemiological investigations, serological examinations, and tests of cure.

One acceptable solution is to employ streptomycin by injection and to associate it with active oral treatment: thus one maintains contact with the patient and achieves a high percentage of cures.

Since 1960, we have studied another regime for clinic patients which is more economical. An antibiotic, active by mouth alone, is taken by the patient on the spot but he is not given any to take away with him. Spiramycin (Rovamycin), which is very active against the gonococcus and is especially well tolerated, is used.

We call this the "minute treatment", after Cuilleret (1940) who used a similar regime with

\footnotetext{
* Paper read at the M.S.S.V.D. meeting in Paris on May, 121961.
}

sulphathiazole at a time when resistance to sulphonamides was unknown. Other authors (see Discussion) have also used oral antibiotics in a single dose to avoid the risk of the out-patient's unreliability in observing a multi-dose treatment schedule.

\section{Method}

After preliminary research at the Institut Fournier and the Hôpital Broussais on the sensitivity of gonococci, serum levels, and cultures in certain patients specially followed up, trials were carried out at the Hôpital Saint-Louis, in the department of Prof. R. Küss, where the abundance of patients with gonorrhoea enabled a large series to be tested quickly. In the first 4 months of 1961 , the number of cases of gonorrhoea seen in consultation was 1,221 (1,075 men and 146 women).

The present study is concerned with 784 men suffering from recent acute gonococcal urethritis, whose ages varied from 17 to 56 , about 75 per cent. of them being North Africans. The same treatment was given to 58 women, whose ages varied from 16 to 52 years. Only two of the women ( 3.4 per cent.) were of North African origin, a difference of epidemiological importance. North Africans living in France often have women brought over from North Africa, and if these become infected venereally, they seldom agree to be examined and cannot usually be traced.

In men, smears stained with methylene blue or Gram's stain were used in diagnosis; cultures on the medium described by Roiron (1954) were done only if there was doubt at the first examination. In women, on the other hand, the diagnosis was always reinforced with cultures, special attention being given to the problem of other members of the Neisseria group.

As soon as the diagnosis was made, the patient was made to take ten tablets $(2 \cdot 5 \mathrm{~g}$.) of Rovamycin: five tablets with a first glass of water and five with a second glass. The tablets were taken in the presence of the doctor, a practice which, amongst other advantages, allowed verification that the drug was actually taken. An effort was made to prevent the patient from remembering 
the name of the product, although, as it was provided free by the hospital, a prescription had not to be given to the patient. The usual advice was given and epidemiological investigations were undertaken by the social worker.

The men were told to return 48 hours after taking the tablets. Generally the urethra was dry and a provocative test was undertaken by instilling 4 to $5 \mathrm{ml}$. 1 per cent. silver nitrate into the urethra. The patient returned 2 to 3 days later for a second provocative test, and again for examination 7 days after treatment, and was then asked to return for serological examination 3 weeks and again 3 months after treatment.

$94 \cdot 3$ per cent. of the patients had one provocative test and were re-examined the following day.

88.7 per cent. of the patients had two provocative tests and were re-examined on the following day.

Although, for various reasons, only a few patients were followed up for a long period, the provocative tests make it likely that relapses would have been rapidly discovered and it is probable that patients having an early relapse would have come back for further advice.

The women were asked to return for the first time 5 to 10 days after treatment; a culture was taken from the cervical canal and from the urethra and a swab soaked in 2 per cent. silver nitrate was introduced into the two canals. A second similar examination was carried out 5 to 6 days after the first. Each time, where possible, the examination coincided with the beginning or the end of menstruation. 32 women were followed up for longer than one month. It is generally believed that spiramycin has a treponemicidal action because, in patients with chancres treated with $3 \mathrm{~g}$. spiramycin daily, $T$. pallidum disappeared in 1 to 3 days (Durel and Pellerat, personal communications; Barbier, 1958). This is an important observation but when one realizes that spiramycin has no action in vitro against $T$. pallidum (Borel, personal communication), it is reasonable to question whether a single dose of $2 \cdot 5 \mathrm{~g}$, could in fact mask incubating syphilis. This special problem, which is of great importance, has not yet been solved.

We tried to persuade our patients to come for a standard serological test to one of the syphilis departments in the hospital, but because of the large number of new patients in the syphilis departments at the Hôpital Saint-Louis we were unable to discover the exact number of patients from the series treated with spiramycin in whom serological tests were performed. They amount to about 20 per cent. of the total, but none of the possible positive cases would have been missed and none was notified to us.

\section{Results}

\section{Sensitivity of Gonococci to Spiramycin}

The results of a study into the current sensitivity of the gonococcus to different antibiotics have been published elsewhere (Roiron, Rasetti-Nicod, and
Durel, 1961). For spiramycin, the study of 61 strains showed the following results:

\begin{tabular}{c|c|c}
\hline \multirow{2}{*}{ Dose $(\mu \mathrm{g} . / \mathrm{ml})}$. & \multicolumn{2}{|c}{ Sensitive Strains } \\
\cline { 2 - 3 } & No. & Per cent. \\
\hline 0.12 & 6 & 10 \\
0.25 & 38 & 62 \\
$0 \cdot 50$ & 16 & 26 \\
1.00 & 1 & 2 \\
\hline Total & 61 & 100 \\
\hline
\end{tabular}

After a complete series of clinical trials, a level of $1 \mu \mathrm{g} . / \mathrm{ml}$. maintained for 5 to 6 hours, can be said to assure the cure of male urethritis. The 61 strains examined can therefore be considered to be sensitive to spiramycin.

\section{Serum Levels and Urinary Excretion}

The necessity for repeated venesection prevented a study of serum levels in gonorrhoea cases treated as out-patients. The study was performed on adults admitted to hospital for various types of infection, usually of the upper respiratory tract. We had not yet decided on a dose of $2.5 \mathrm{~g}$. and these patients received $2 \mathrm{~g}$. in one dose. It is reasonable to assume that the serum levels would have been slightly higher after $2 \cdot 5 \mathrm{~g}$. The results for $2 \mathrm{~g}$. were as follows:

\begin{tabular}{c|c|c|c}
\hline \multirow{2}{*}{$\begin{array}{c}\text { No. of } \\
\text { Patients }\end{array}$} & $\begin{array}{c}\text { Interval of Time after } \\
\text { taking Tablets (hrs) }\end{array}$ & \multicolumn{2}{|c}{ Serum Level $(\mu \mathrm{g} . / \mathrm{ml})}$. \\
\cline { 3 - 4 } & & Average & Median \\
\hline \multirow{2}{*}{13} & 2 & $1 \cdot 50$ & $1 \cdot 44$ \\
& 4 & $2 \cdot 22$ & $2 \cdot 12$ \\
& 6 & $1 \cdot 89$ & $1 \cdot 59$ \\
\hline 7 & 24 & $0 \cdot 35$ & 0.34 \\
\hline
\end{tabular}

The figures are considerably higher than those for sensitivity in vitro.

The urinary excretion in eight patients was as follows:

\begin{tabular}{c|c}
\hline $\begin{array}{c}\text { Interval of Time after } \\
\text { taking Tablets (hrs) }\end{array}$ & $\begin{array}{c}\text { Urinary Excretion } \\
\text { (mg./l.) }\end{array}$ \\
\hline 0 to 24 & 150 \\
24 to 48 & $15 \cdot 4$ \\
48 to 72 & $7 \cdot 7$ \\
72 to 96 & $3 \cdot 3$ \\
\hline
\end{tabular}




\section{Clinical Results}

These can be summarized easily.

In men, a cure (i.e. disappearance of gonococci and almost always absence of secretion and normal appearance of the mucosa, after one or two provocative tests) was achieved in $764(97.4$ per cent.) of the 784 patients. It is interesting to note that the number of cases of non-gonococcal urethritis following gonorrhoea was very small, perhaps because our patients came for advice in the early stages of their urethritis and also because of the action of the silver nitrate.

In women, the cure rate was of the same order; in 57 cases out of $58(98 \cdot 1$ per cent.) the gonococci had disappeared after provocative tests at about the 10th day.

Failures were treated with 1 to 2 mega units penicillin and all were cured after this second course of treatment.

Tolerance of this dose $(2 \cdot 5 \mathrm{~g}$.) of spiramycin was excellent; 21 patients reported a slight gastric "heaviness" but there was neither vomiting nor diarrhoea.

\section{Discussion}

We have used the "minute treatment", employing a single dose, for two reasons:

(1) To be certain that the chosen dose is actually taken,

(2) To make it necessary for the patient to return to the clinic in the case of treatment failure. This allowed epidemiological investigations to be undertaken and prevented the danger of self-treatment.

Other authors, using other antibiotics, have put forward the same objectives, but principally for the first reason, and their work has been concerned only with acute urethritis in the male.

Chloramphenicol was used by Smadel, Bailey, and Mankikar (1949), Robinson and Robinson (1949), Greaves, McDonald, Romansky, and Taggart (1950), and above all by Barrett and Burton (1953), who treated 481 men. The results of this last series were assessed after 7 days because afterwards 50 per cent. of the patients disappeared. With $1 \mathrm{~g}$., there were $84 \cdot 5$ per cent. of clinical cures and $88 \cdot 7$ per cent. of bacteriological cures in 251 patients treated. With $2 \mathrm{~g}$., the corresponding figures were 87.7 and 93.6 per cent. in 226 patients. Some patients complained of minimal gastric pain which was not serious. In cases re-examined between the 5th and 20th day after treatment, bacteriological cure was about the same ( 92 and $92 \cdot 2$ per cent.) for the two doses used.

Oxytetracycline was used by Robinson $(1950 \mathrm{a}, \mathrm{b})$ and by Schoch and Alexander (1950), who found that the gonococci had disappeared 24 hours after a dose of $1 \mathrm{~g}$. in 23 out of 26 patients ( $95 \cdot 3$ per cent.).

Tetracycline was studied by Buckinger and Hookings (1954-55), whose results may be tabulated as follows:

\begin{tabular}{c|c|c|c}
\hline $\begin{array}{c}\text { No. of } \\
\text { Cases }\end{array}$ & $\begin{array}{c}\text { Dose } \\
\text { (g.) }\end{array}$ & $\begin{array}{c}\text { Cure Rate } \\
\text { (per cent.) }\end{array}$ & $\begin{array}{c}\text { Side-effects } \\
\text { (Nausea) }\end{array}$ \\
\cline { 2 - 3 } 150 & 1.0 & $84 \cdot 7$ & 4 \\
150 & 1.5 & 92.7 & 6 \\
150 & 2.0 & $97 \cdot 3$ & 7 \\
\hline
\end{tabular}

Cure was assessed clinically and by stained smear. The majority of the patients were followed for 5 months from a serological point of view, but no abnormal S.T.S. were found.

Dimethylchlortetracyline has been used more recently by Pochi and Strauss (1961). The patients received $900 \mathrm{mg}$. in one dose and were followed with smears and cultures for from 7 to 21 days, 32 ( 88.8 per cent.) of 36 patients followed being cured. Six patients (16.6 per cent.) complained of nausea or vomiting and/or diarrhoea or headache; two vomited half an hour after taking the capsules but were nevertheless cured.

Erythromycin belongs to the same group of antibiotics as spiramycin. Gable, Romansky, and Taggart (1953) gave $2 \mathrm{~g}$. in one dose to seven patients who were followed for from 7 to 14 days with smears and cultures. All were cured but tolerance was poor, five of the seven patients having to stop work for 24 hours.

Oleandomycin also belongs to the erythromycin group and has a known action on gonorrhoea. Delouche (1961) used the triacetyl derivative in a single dose of $2 \mathrm{~g}$. in 115 male patients, and a cure (confirmed by two controlled provocative tests) was obtained in $102(88.6$ per cent.). This percentage reached 97 per cent. if $1 \mathrm{~g}$. streptomycin was given at the same time.

\section{Summary}

Because of the danger of serious reactions to penicillin given for a benign condition like gonorrhoea and because of the growing failure rate with streptomycin, the use of another antibiotic must be 
considered. Excluding these two products, only oral antibiotics, for practical purposes, remain. These have two drawbacks, in that the patient may not follow the prescribed treatment, and/or in the event of re-infection may try self-treatment which, if successful, will prevent epidemiological investigation. Several authors, thinking principally of the first drawback, have used oral antibiotics in a single dose, and have reported favourable results in about 90 per cent. of cases.

Thinking principally of the danger of self-treatment, we have employed an antibiotic not previously used in this way, namely, spiramycin (Rovamycin N.D.). We gave a single dose of 2.5 g., without revealing the name of the drug, so that the patient would not be able to treat himself in the event of reinfection.

The cure rate was 97.4 per cent. in 784 men and $98 \cdot 1$ per cent. in 58 women. This antibiotic is noted for its good tolerance and we had no toxic sideeffects worthy of note.

In a previous study of the sensitivity of 61 strains of gonococci to spiramycin, the required serum level was found to be less than $1 \mu \mathrm{g} . / \mathrm{ml}$., a level which is very easily reached in the blood, as shown by tests on thirteen patients.

\section{REFERENCES}

Barbier, C. (1958). “Au sujet de 100 cas de syphilis traités par la spiramycine." Thèse, Paris, No. 307.

Barrett, C. Dale, and Burton, M. E. (1953). Amer.J. Syph., 37,165 .

Buckinger, R. H., and Hookings, C. E. (1955). "Antibiotics Annual, 1954-1955", p. 574.

Cuilleret, P. (1940). Rev. méd. Fr., p. 357.

Delouche, L. (1961). Presse méd., 69, 1035.

Gable, G. R., Romansky, M. J., and Taggart, S. R. (1953). Amer.J. Syph., 37, 377.

Greaves, A. B., MacDonald, G. R., Romansky, M. J., and Taggart, S. R. (1950). J. vener. Dis. Inform., 31, 261.

Pochi, P. E., and Strauss, J.S. (1961). Antibiot. Med., 8, 75. Robinson, H. M., and Robinson, H. M., jr. (1949). Sth. med. J., 42, 988 .
Robinson, R. C. V. (1950a). Amer. J. Syph., 34, 64. (1950b). Ibid., 34, 587.

Roiron, V. (1954). Presse méd., 62, 686.

- , Rasetti-Nicod, G., and Durel, P. (1961). Ann. Inst. Pasteur, 100, 445.

Schoch, A. G., and Alexander, L. J. (1950). Ann. N.Y. Acad. Sci., 53, 459.

Smadel, J. E., Bailey, C. A., and Mankikar, D. S. (1949). J. clin. Invest., 28, 964.

\section{Nouveau "traitement-minute" de la gonococcie RÉSUMÉ}

Devant la crainte que l'on peut avoir d'employer la pénicilline pour une maladie bénigne comme la gonococcie: devant les échecs croissants de la streptomycine, on est conduit à envisager l'emploi d'un autre antibiotique. En dehors des antibiotiques précédents, il n'y a, pratiquement, que des produits utilisables par voie orale et ceci a deux inconvénients:

(1) Le malade peut négliger de suivre le traitement prescrit;

(2) En cas de réinfection, il risque de se traiter lui-même - plus ou moins bien - et l'enquête épidémiologique devient impossible.

Divers auteurs, pensant surtout au premier inconvénient, ont utilisé les antibiotiques oraux en prise unique, avec des résultats favorables dans environ 9 cas sur 10.

Pensant surtout au second inconvénient signalé, nous avons eu recours à un antibiotique non encore utilisé de cette manière: la spiramycine (Rovamycine N.D.), que nous avons donné au malade à la dose de $2,50 \mathrm{~g}$. en une prise, sans en préciser le nom, afin que le malade ne puisse, en cas de réinfection, se traiter lui-même. 784 hommes furent traités, avec $97,4 \%$ de guérison, et 58 femmes furent traitées, avec $98,1 \%$ de guérison.

Cet antibiotique est connu pour sa bonne tolérance; nous n'avons eu aucun incident vraiment digne d'être noté.

Nous avions, auparavant, étudié la sensibilité de 61 souches de gonocoques à cet antibiotique; elle fut, dans tous les cas, inférieure à $1 \mu \mathrm{g} . / \mathrm{ml}$., taux facilement atteint dans le sang, comme nous avons pu nous en assurer par des dosages chez 13 malades. 